\title{
PENYAKIT BERBASIS AIR DAN VEKTOR \\ Oleh
}

\section{ERIS JUNIKA}

\section{Pendahuluan}

Di seluruh dunia, sekita 2 miliar orang bermasalah dengan akses air minum. Lebih dari setengah populasi dunia tidak memiliki akses sanitasi aman.Tiga miliar orang tidak memiliki akses ke fasilitas cuci tangan pakai sabun. Namun, 673 juta orang masih melakukan buang air besar sembarangan.(Organization, 2019)

Air merupakan salah satu sumber daya alam yang memiliki fungsi sangat penting bagi kehidupan dan perikehidupan manusia serta mahkluk hidup lainnya, sehingga harus dijaga kualitasnya untuk kepentingan generasi sekarang dan yang akan datang serta keseimbangan ekosistem.(Wulandari \& llyas, 2019)

Air sangat penting untuk kehidupan, tetapi banyak orang tidak memiliki akses air minum yang bersih dan aman dan banyak yang meninggal karena infeksi bakteri yang ditularkan melalui air. Penyakit yang ditularkan melalui air disebabkan oleh mikroorganisme patogen yang ditularkan secara langsung ketika air minum yang dikonsumsi terkontaminasi. Penyakit yang ditularkan melalui air dapat disebabkan oleh protozoa, virus, atau bakteri, banyak di antaranya adalah parasit usus. Secara umum, risiko mikroba terbesar terkait dengan konsumsi air yang terkontaminasi dengan kotoran manusia atau hewan. Pembuangan air limbah di sungai maupun perairan laut merupakan sumber utama mikroorganisme tinja yang patogen.

\section{Hasil Rangkuman}

Penyakit yang ditularkan melalui air tetap menjadi penyebab utama morbiditas dan mortalitas manusia di seluruh dunia. Lebih dari $95 \%$ 
penyakit yang ditularkan melalui air dapat dicegah. Infeksi yang ditularkan melalui makanan dan air sering terjadi pada cacing dan protozoa, meskipun kontaminasi langsung dari orang ke orang, fekal-oral juga bertanggung jawab untuk menularkan beberapa infeksi. Kebersihan pribadi yang baik dan perbaikan infrastruktur sanitasi untuk pencegahan dan pengendalian penyakit. Dampak potensial pada kesehatan masyarakat dari infeksi yang ditularkan melalui air dan vektor. Kemungkinan perubahan iklim; peningkatan frekuensi kejadian hujan lebat, dengan banjir terkait dan peningkatan suhu. Banjir dikaitkan dengan peningkatan risiko infeksi di negara berkembang. Ada banyak laporan tentang wabah yang mengikuti banjir yang menyebabkan kontaminasi sumber air minum masyarakat. kondisi iklim yang mendukung peningkatan penyakit yang ditularkan melalui vektor tertentu seperti malaria.(Hayat \& Kurniatillah, 2009)

Vektor merupakan organisme hidup yang dapat menularkan infeksi patogen antar manusia, atau dari hewan ke manusia. Banyak dari vektor ini adalah serangga penghisap darah, yang menelan mikroorganisme penyebab penyakit selama makan darah dari inang yang terinfeksi (manusia atau hewan) dan kemudian menularkannya ke inang baru, setelah patogen bereplikasi. Seringkali, begitu vektor menjadi menular, mereka mampu menularkan patogen selama sisa hidup mereka selama setiap gigitan/makanan darah berikutnya. Penyakit tular vektor adalah penyakit manusia yang disebabkan oleh parasit, virus dan bakteri yang ditularkan oleh vektor. Setiap tahun ada lebih dari 700.000 kematian akibat penyakit seperti malaria, demam berdarah.(Hayat, Nurdiawati, et al., 2021)

Limbah berbahaya dan infeksius dari rumah sakit(Hayat, 2015) berdampak pada pencemaran air sungai dan laut. Limbah aktivitas manusia melalui tinja dibuang ke dalam sungai mengakibtkan peningkatan kadar E.coli tinja.(Hayat \& Kurniatillah, 2021) Aktivitas industri 
mengakibatkan limbah Chlor bebas melebihi baku mutu air sungai.(Hayat, 2020)

Faktor perilaku masyarakat yang tidak baik berpengaruh terhadap penanganan limbah medis infeksius,(Hayat, 2012) menyebabkan penyakit berbasis air.(Hayat, 2020) Oleh karena itu, diperlukan pencegahan dan pengendalian melalui sarana Komunikasi, Informasi dan Edukasi pada masyarakat(Hayat, 2012) juga dibutuhkan peran keluarga sebagai penentu keputusan dalam keluarga.(Hayat, Arifiati, et al., 2021) Disamping itu, masyarakat juga harus memanfaatkan pelayanan kesehatan terutama puskesmas (Kurniatillah \& Hayat, 2021) dalam rangka mendapatkan pelayanan konseling terkait penyakit berbasis air dan vektor penyakit. Dalam rangka memperkuat upaya perilaku hidup bersih dan sehat, mencegah penyebaran penyakit berbasis lingkungan, meningkatkan kemampuan masyarakat, serta meningkatkan akses air minum dan sanitasi dasar, perlu menyelenggarakan sanitasi total berbasis masyarakat.

\section{Kesimpulan}

Penyelenggarakan sanitasi total berbasis masyarakat, Perilaku Hidup Bersih dan Sehat dan kondisi sanitasi yang baik dan aman mencegah dan mengendalikan penyakit yang ditularkan melalui air dan vektor.

\section{Referensi}

Hayat, F. (2012). Pengaruh predisposing factor, Enable factor, Reinforcing factor terhadap praktik keselamatan kerja pada tenaga kesehatan dalam pengelolaan limbah medis padat di Puskesmas Wilayah Kota Cilegon tahun 2011. In Unpad Repository. Unpad.

Hayat, F. (2015). Analisis faktor pengelolaan limbah medis padat di Rumah Sakit Umum Daerah Kota Cilegon. Faletehan Health Journal, 3, 146-151.

Hayat, F. (2020). Analisis Kadar Klor Bebas (Cl2) dan Dampaknya Terhadap Kesehatan Masyarakat di Sepanjang Sungai Cidanau Kota 
Cilegon. Jurnal Kesehatan Masyarakat Mulawarman (JKMM), 2(2), 64-69.

Hayat, F., Arifiati, N., \& Permatasari, T. A. E. (2021). Peran Dukungan Suami dan Faktor Lainnya terhadap Pemanfaatan Pelayanan Gizi oleh Ibu Hamil dengan Risiko Kurang Energi Kronis (KEK). Jurnal Keperawatan Silampari, 5(1), 125-133.

Hayat, F., \& Kurniatillah, N. (2009). Situasi Malaria di Kabupaten Lebak. Kesmas: Jurnal Kesehatan Masyarakat Nasional (National Public Health Journal), 3(6), 259-263.

Hayat, F., \& Kurniatillah, N. (2021). Microbiological and Water Quality Status of Cibanten River. The First International Conference on Social Science, Humanity, and Public Health (ICOSHIP 2020), 198-200.

Hayat, F., Nurdiawati, E., \& Kurniatillah, N. (2021). EDUKASI GERAKAN PEMBERANTASAN NYAMUK (PSN) DEMAM BERDARAH PADA ANAK USIA SEKOLAH DASAR DI KECAMATAN JAWILAN KABUPATEN SERANG.

Kurniatillah, N., \& Hayat, F. (2021). ANALISIS PERILAKU PEMANFAATAN PELAYANAN KLINIK SANITASI PUSKESMAS OLEH KELUARGA DENGAN PENYAKIT TUBERKULOSIS PARU BTA (+) DI KECAMATAN TAKTAKAN KOTA SERANG. JOURNAL OF BAJA HEALTH SCIENCE, 1(02), 107-114.

Organization, W. H. (2019). World health statistics 2019: monitoring health for the SDGs, sustainable development goals. World Health Organization.

Wulandari, A. S. R., \& llyas, A. (2019). Pengelolaan Sumber Daya Air di Indonesia: Tata Pengurusan Air dalam Bingkai Otonomi Daerah. Gema Keadilan, 6(3), 287-299. 